\title{
PARADIGMATIC PERSPECTIVES ON INCOME DISTRIBUTION AND FINANCIAL CRISES
}

\author{
Sinem SEFIL *
}

\begin{abstract}
The role of the income distribution and inequality among individuals and factors of production on the occurrence of financial crises has long been a controversial issue in economics literature and the stance of the economists on this debate is mainly rooted in their different views on the distributional mechanism in the economic system. By conducting an extensive literature review, this paper attempts to illustrate the views of the different schools of economic though on role of income distribution and inequality as a cause of the financial crises with a special focus on the subprime crisis in 2008.
\end{abstract}

Keywords: Income distribution, financial crises. crisis theories, subprime crisis.

JEL Classification: B10; D30; G01

\section{GELIR DAĞILIMI VE FINANSAL KRIZZLER ÜZERİNE PARADİGMATİK GÖRÜŞLER}

\section{Özet}

Bireyler ve üretim faktörleri arasındaki gelir dağılımı ve eşitsizliğin finansal krizlerin oluşumundaki rolü iktisat literatüründe çok tartışılan bir konudur ve iktisatçıların bu tartışmadaki duruşları önemli ölçüde iktisadi sistemde gelir dağılımının rolüne ilişkin görüşleriyle ilişkilidir. Bu çalışma, farklı iktisadi okulların gelir dağılımı ve eşitsizliğin finansal krizlerin oluşumundaki rolüne ilişkin açıklamalarını, 2008'de gerçekleşen subprime krizi üzerine yoğunlaşarak, kapsamlı bir literatür taraması yoluyla açıklamayı amaçlamaktadır.

Anahtar kelimeler: : Gelir dağılımı, finansal krizler, kriz teorileri, subprime krizi.

JEL Sınıflaması: C45, N20, C53

\footnotetext{
* Lecturer Dr, Istanbul Commerce University, Department of Economics (Eng)., ssefil@ticaret.edu.tr
} 


\section{Introduction}

Although the possible causes and consequences of the financial crises have been reviewed by a great number of studies from different strands of economics, one the most discussed and debated issues is that of income distribution which comprises two measures: personal income distribution which refers to the distribution of national income among individuals or households and the functional income distribution which examines how the national income is shared by the two main factors of production, namely labor and capital.

Inferring the direction of the causality between financial crises and inequality among individuals and factors of production has long been a controversial issue and the stance of the economists on this debate is mainly rooted in their different views on the distributional mechanism in the economic system. Although the effects of income redistribution among households and the main factors of production on the economic system was a conspicuous subject in the discussions of the $19^{\text {th }}$ and $20^{\text {th }}$ century classical economists, in particular Marx, Smith, Ricardo and Keynes, the dominance of the neoclassical economics which does not consider inequality a destabilizing factor, threw inequality out of focus in the last quarter of the 20th century. However, economists from heterodox tradition, particularly Marxists and post-Keynesians have continued to examine the impacts of the changes in income distribution on the economic system ${ }^{1}$. Crises have also been theorized predominantly by heterodox economists, since the neoclassical or mainstream economists see the economy as a stable system and crises as exogenous shocks, while economists from heterodox tradition agree that capitalist economies are inherently unstable and prone to crises due to their endogenous forces.

The eruption of the global financial crisis in 2008 stimulated interest in the relationship between income inequality, credit booms, and financial crises ${ }^{2}$. High levels of economic inequality and the increasing top income prior to the occurrence of the subprime crisis have been discussed and examined by an increasing number of economists from different strands of economics. Such discussions have revealed that many of the individual explanations of financial crises in different economic traditions do not offer a complete overview of the subprime crisis and its transformation to the global financial crisis itself.

By conducting an extensive literature review, this paper attempts to illustrate the paradigmatic perspective changes of the different strands of economics regarding the views on the relationship between income distribution and financial crises in conjunction with various economists' explanations on the eruption of the subprime crisis and its transformation to the global financial crisis. Considering the fact that different strands of economics have diverging interpretations as to why financial crises occur, it is necessary to begin initially with a comprehensive explanation

1 Thomas Goda. "The role of income inequality in crisis theories and in the subprime crisis." Post Keynesian Economics Study Group Working Paper, 1305. 2013.

2 Michael Bordo-Christopher M. Meissner. Does inequality lead to a financial crisis?. Journal of International Money and Finance. 2012. 31(8): 2147-2161. 
of different theories of financial crises and the role of income distribution in these theories before the role income distribution in the subprime crisis can be fully comprehended. This review will be limited to three heterodox schools of economics whose theories of financial instability are widely used to explain the global financial crisis-Marxism, post-Keynesianism, and the Austrian school-and to the two dominant schools of economics at the present time-neoclassical and new-Keynesian economics - which will be referred to as mainstream economics.

This paper is organized as follows: Section 1.2 and 1.3 reviews the role of income distribution in heterodox and mainstream crisis theories respectively. Section 1.4 and 1.5 discuss the link between income distribution and the occurrence of the subprime crisis and its transformation of global financial crisis in heterodox and mainstream crisis theories respectively. Section 1.6 provides a summary and conclusion.

\section{Heterodox Crisis Theories and Income Distribution}

Heterodox economics is an umbrella term covering various approaches, methodologies, schools, or traditions of economics that are considered outside of mainstream economics due to their rejection of the stylized notions of conventional economics ${ }^{3}$. One of the common denominators on which different heterodox strands of economics agree is that capitalist economies are inherently unstable and tend to have instability due to their endogenous contradictions. The tendency of the economic system to have instability has been discussed by a number of heterodox theories, which mostly belong to Marxist and post-Keynesian in particular. However, there are diverging ideas on the relationship between income distribution and the occurrence of crises not just among these strands, but also within each strand.

Marxian economics puts the inequality and redistribution at the heart of the economic analysis relying on its main mechanism, which focuses on the class struggle between workers and capitalists. Based on the fundamental notion that capitalist economy is an inherently unstable system with fundamental inner contradictions that ultimately cause an economic downturn, All Marxian crisis theories see the fall in the profit rates stemming from internal inconsistencies in the capitalist system as the trigger of the crisis. Marxian economists' disagreement on the main reason for the fall in the profit rates brought on the development of different Marxian crisis theories. This variety of crisis theories in Marxian economics mostly arose from the absence of an integrated crisis theory in Marx's own discussions. Marx explained the fall in the rate of profits as related to the tendencies of under-consumption, over-production, over-accumulation, and disproportionality with respect to labor, without prioritizing any of them ${ }^{4}$. On that note of Marx's text, three main Marxian theories emerged to explain capitalist crises. In spite of the fact that none of the original versions of these theories are related to the financial markets and credit booms in

3 Tony Lawson. Essays on: The Nature and State of Modern Economics. Routledge. 2015.

4 Simon Clarke. Marx's Theory of Crisis. Macmillan Press: Basingstoke. 1994 
principle, they have all been reinterpreted by the heterodox economists to explain the global financial crisis. One of these three approaches is the "under-consumption" theory of crises, which explains a crisis as a result of the fall in the rate of profits derived from under-consumption, i.e., lack of effective demand that is necessary for the consumption of the commodities produced by capitalists. The second approach is the "profit squeeze" theory that claims that either the scarcity "variable capital (labor)" or/and "constant capital" (e.g., raw material, machines) eventually result in a squeeze in capitalist" profits with higher costs. The last one is the theory of the "tendency for the rate of profit to fall" that emphasizes the role of increasing ratio of constant capital to variable capital in crisis as a consequence of the inner contradiction of the capitalist process. ${ }^{5}$

According to Marx's theory, surplus value, which is the source of capitalists' profit, is obtained by the exploitation of variable capital. Output is composed of two components, which are the output paid as wages to workers and the output received by capitalists; the smaller the first component, the higher the surplus value created by labor. So other things being equal, the surplus value increases with a decreasing real wage and increasing working time and/or output. On the other hand, the main success indicator of capitalists is the profitability of their investments in variable and constant capital. Thus, they prefer to use less labor per unit produced to reduce unit costs ${ }^{6}$. In addition, Marxian theory accepts unemployment as inherent in a capitalist economy and gives it significant importance for the comprehension of income and wealth distribution.

According to the supporters of the under-consumption theory of crises, unequally distributed income among classes and/or individuals is the main underlying reason behind capitalist crises. Going back to the discussions of Thomas Malthus in the 1820s, the under-consumptionist tradition includes various interpretations. While the traditional explanations of this theory fundamentally indicates the lack of effective demand as the trigger of the crises, a number of studies link the under-consumption and overproduction by emphasizing the tendency of capitalist economies to create an excessive production capacity, and the lack of effective demand for consuming the output results in an absolute economic downturn ${ }^{7}$.

Since capitalists always maximize their profits, they aim to increase their output and reduce employment and wages. On the other hand, since the goods produced by capitalists need to be sold, the success of the capitalists' strategy is ultimately bounded by the purchasing power of the working class. When the production reaches a point where it cannot be absorbed by effective demand, capitalists' rate of profit subsequently falls. Eventually, a widening income gap, i.e., increasing income inequality between classes, results in a crisis.

The profit squeeze theory, on the other hand, claims that reduced income inequality between

5 Anwar Shaikh. The first great depression of the 21st century. Socialist Register. 2011. 47: 44-63.

6 Goda, Ibid.

7 See Paul Baran and Paul Marlor Sweezy. Monopoly capital: An essay on the American economic and social order. Vol. 73. NYU Press. 1966; Foster Magdoff, et al. The New Face of Capitalism: Slow Growth, Excess Capital, and a Mountain of Debt. Monthly Review. 2002. 53(11): 1-14. 
workers and capitalists causes a fall in the rate of the profit, which results in a crisis. According to this theory, being in search of more profit, capitalists perpetually expand their scale of operation, which leads to a reduction in the unemployment rate (i.e., a reduction in the reserve army of the unemployed). As a consequence, workers' and unions' bargaining power increases, resulting in an increase in real wages and squeezing profits ${ }^{8}$. This theorem indicates that profit squezee occurs when the increase in real wages exceeds the increase in labor productivitiy and a change in the income distribution in favor of workers is the main cause of capitalist economic crises.

According to the third Marxist theory, the "tendency for the profit rate to fall," income redistribution among classes is not a source of capitalist crises, but it is one of the consequences of capitalist accumulation. Being under the pressure of increasing productivity and expanding production with a high level of competition, capitalists tend to replace the variable capital with constant capital, i.e., replacing the labor force with more machinery. The rate of profit starts to fall at a point where the increase in the constant capital is greater than the increase in the level of exploitation as a result of the high level of mechanization in the production process; then, the economic downturn begins ${ }^{9}$. Consequently, the increasing mechanization in production process, which is the main reason for capitalist crises, is not derived from the increasing bargaining power of workers or the high level of real wages; rather, it is caused by the capitalists' pursuit of more profit.

Building upon a radical interpretation of The General Theory of John Maynard Keynes and welcoming the contributions of a wide range of fields of study such as political science, sociology, anthropology, history, and psychology, post-Keynesian economics is a heterogeneous theory consisting of various strands which all meet at some common features, such as their emphasis on institutional and social factors, non-neutrality of money, critical realism, uncertainty of economic processes, and accepting the effective aggregate demand as the determinant of the economy ${ }^{10}$. As such in the Marxian economics, the conflict between capitalists, workers, and rentiers and the redistribution of income and wealth among them are at center of the post-Keynesian analysis ${ }^{11}$. The theorizing of financial crises in post-Keynesian tradition is mostly shaped by the financial instability hypothesis of Minsky (1982), the stock-flow-consistent model of Godley (1999) and financialization theory.

Forming a link between real and financial sectors, Minsky's (1982, 1986) financial instability

8 See Jonathan Goldstein. The cyclical profit squeeze: a Marxian microfoundation. Review of Radical Political Economics. 1985. 17(1-2): 103-128; Fred Moseley. The rate of profit and the future of capitalism. Review of Radical Political Economics. 1997. 29(4): 23-41 and Laurent Baronian, Marx and Living Labour. Routledge. 2013

9 See Anwar Shaikh. An introduction to the history of crisis theories. In "US Capitalism in Crisis. Union for Radical Political Economics: New York. 1978; David Laibman. Value, technical change, and crisis: Explorations in Marxist economic theory. ME Sharpe. 1992; Peter Bell and Harry Cleaver. Marx's theory of crisis as a theory of class struggle. The Commoner. 2002. 5:1-61 and Trevor Evans. Marxian and post-Keynesian theories of finance and the business cycle. Capital \& Class. 2004. 28(2): 47-100.

10 Marc Lavoie. Introduction to Post-Keynesian Economics. Houndmills: Palgrave Macmillan. 2006.

11 Philip Arestis. Post-Keynesian economics: towards coherence. Cambridge Journal of Economics. 1996. 20(1): 111135. 
hypothesis emphasizes the debt structure dynamics of the non-government sector as the key element that causes crises which are inherently unavoidable due to the functioning of the financial markets in the economic system. Minsky identified three types of borrowing positions for firms: hedge financing, speculative financing, and Ponzi financing. While the first one is based on making future payments by a certain income and including a minor risk for the creditor, the second is based on making future payments by a combination of cash (for covering interest due) and debt (re-borrowing for the principal payments) and including a moderate level of risk for the creditor. The third one, on the other hand, indicates the situation where the borrowers can only pay the interest by their income and re-borrowing, and thus contains the highest level of risk for the creditor. The higher the risk incurred by the creditor, the higher the risk premium incurred by the borrower. In a capitalist economy, firms tend to incur debt for financing their future investments with high return expectations. With the increasing investment demand, profits will also increase, and this economic loop results in an economic boom. Inevitably, when the rise in the investment supply falls behind the drastic rise in the investment demand, short-run interest rates increase rapidly with a domino effect that induces increased medium and long-run rates. As a result of the continuously decreasing rate of profits, firms become unable to fulfill their financial commitments and turn to more speculative and Ponzi financing options. Consequently, the financial system collapses ${ }^{12}$. Minsky's financial instability hypothesis offers a comprehensive explanation for the financial disturbances in post-war periods. However, being limited to firms only and their pursuit of higher rates of profit, its theoretical framework is mainly based on the expectations and effective demand and lacks an examination of the relation between income distribution and financial stability ${ }^{13}$. On the other hand, there have been some efforts to extend this hypothesis with an inequality perspective, which will be discussed further.

Another post-Keynesian effort that focuses on the dynamics of the private sector's debt accumulation causing a crisis is the stock-flow consistent approach, mostly formed by Godley (1999) and Godley and Lavoie $(2001,2007)$. The main principle of this approach is dividing the economy into sectors and examining the flows between them based on the notion that every money flow comes from somewhere and goes somewhere. Developing the model of Godley (1999), Lavoie and Godley (2001), Godley and Lavoie (2001, 2007a, 2007b) proposed a more elaborated model in which the production decisions of private sector (firms) are financed by money created by banks; they claimed that the main reason the capitalist economy is pushed toward a crisis is the unsustainable imbalances in inter-sectoral flows. Without setting an assumption on different social classes' propensity to consume, a reduction in real wages caused by an increase in the costing margin has a distorting effect on output and the labor market due to the higher inflation rates linked to a greater struggle over the distribution of income arising

12 See Domenico Delli Gatti and Mauro Gallegati. Financial instability, income distribution, and the stock market. Journal of Post Keynesian Economics. 1990. 12(3): 356-374 and

13 See Marc Jarsulic, Financial instability and income distribution. Journal of Economic Issues. 198822(2), 545553. 1988 and Elom Ezuho. Income Inequality, Over-indebtedness and Financial Instability: Essay on a KeynesGoodwin-Minsky Macrodynamic Model. In 15th Conference of the Research Network Macroeconomics and Macroeconomic Policies (FMM), Berlin 2011. pp. 28-29. 
from the increases in prices $^{14}$. On the other hand, this approach has lack capturing the income distribution among individuals in a macroeconomic sector or dividing households into rentiers and households ${ }^{15}$.

Post-Keynesian economists have been discussing the distorting effects of "financialization" on the economy within the context of the struggle of the different classes over income distribution. The increasing influence and significance of the financial motives, financial institutions, and financial actors in the functioning of the global economic system have been widely defined as financialization in the literature ${ }^{16}$. In comparison with the mainstream models that ignore the effective demand and the struggle between social classes and associate the increasing role of financial intermediation with increasing growth in the long run, post-Keynesian effective demand-based models have been heavily pessimistic about the effects of financialization on the income distribution and growth process ${ }^{17}$. While the early post-Keynesian business cycle models do not include the interaction between financial markets, inequality, and economic stability, post-Keynesian studies examining this issue and interpreting the post-Keynesian business cycle theories with a synthesis of financialization began to show an increase in the 90s, in parallel with the increasing in the degree of financialization and economic instability.

Resulting in an income redistribution in favor of rentiers, financialization affects the aggregate investment level, negatively increasing shareholder value orientation, i.e., ensuring high share prices by paying high dividends to shareholders and buying them back instead of using retained profit to boost the capital. As a result, non-financial firms that have difficulties financing their investments and their debt accumulation become unstainable. Therefore, in finance-dominated capitalist economies, capital accumulation tends to decline ${ }^{18}$ and when the fall in the investment activities cannot be compensated by household consumption, a crisis erupts. Moreover, financialization may trigger a crisis if it causes an unstainable debt accumulation in the household sector due to the decreasing wage share, which leads an increase in the income inequality, which will be discussed further.

14 See Marc Lavoie. Financialisation issues in a Post-Keynesian stock-flow consistent model. Intervention. European Journal of Economics and Economic Policies. 2008. 5(2):335-361 and Steve. Keen. Post Keynesian theories of crisis. American Journal of Economics and Sociology. 2015. 74(2): 298-324.

15 Jo. Michell. A Steindlian account of the distribution of corporate profits and leverage: A stock-flow consistent macroeconomic model with agent-based microfoundations. Post-Keynesian Study Group. Working Paper:14.12. 2014b.

16 See Engelbert Stockhammer. Financialisation and the slowdown of accumulation. Cambridge Journal of Economics. 2004. 28(5): 719-741; Engelbert Stockhammer. Some stylized facts on the finance-dominated accumulation regime. Competition \& Change. 2008. 12(2): 184-202; Eckhard Hein. A (Post-) Keynesian perspective on" financialisation" (No. 1/2009). IMK Study. 2009 and Till van Treeck. The macroeconomics of 'financialisation' and the deeper origins of the crisis. IMK Working Paper No. 9. 2009.

17 Hein, Ibid.

18 See Özgür Orhangazi. Financialisation and capital accumulation in the non-financial corporate sector: A theoretical and empirical investigation on the US economy: 2003-1973. Cambridge Journal of Economics. 2008. 32(6): 863886 and Eckhard Hein. Financialization, distribution, capital accumulation, and productivity growth in a postKaleckian model. Journal of Post Keynesian Economics. 2012. 34(3): 475-496. 
Another heterodox strand of economics whose arguments on financial instability have been used widely to explain the global financial crisis is the Austrian school of economic thought. Unlike the Marxian school with its belief that the free market economy is self-destructive and the postKeynesian production factors and the mechanism of price as the most efficient way to allocate income among individuals ${ }^{19}$. In other words, Austrian economics see income inequality as a natural consequence of economic agents' productive contributions. According to the Austrian theory, an intervention involving income redistribution would damage the economy instead of stimulating it. For instance, a tax increase causes the destruction of wealth or the confiscation of property that would otherwise have been invested ${ }^{20}$. The explanation of Austrian economics as to why financial instability occurs is offered by the Austrian Business Cycle Theory, which claims that crises occur due to the artificial and unsustainable credit-induced booms deriving from the state institutions' intervention in the credit market. Low interest rates induced in the market bschool with its skepticism on free markets, the Austrian school puts great emphasis on the free market for the sustainability of the economic system, similar to neoclassical economics, and defines the free ownership of the y central banks tend to increase borrowing from the banking system. The resulting excessive credit creation and a mismatch between savings and investment eventually cause instability in the financial markets, leading to a recession ${ }^{21}$. Unlike the other crisis theories, the Austrian Business Cycle Theory sees a crisis as a healing time that must be experienced by the economy to recover ${ }^{22}$.

\section{Mainstream Crisis Theories and Income Distribution}

Orthodox/mainstream economists see crises as exceptional deviations from the routine mechanism of a self-regulating economic system instead of being inherent or internally generated in a capitalist economy, as the heterodox tradition supports. In an economic environment where there is no asymmetrical information, all the economic agents are rational and behave homogenously with the motive of utility maximization, full employment always prevails, and financial markets are fully efficient in a world of perfect certainty where the neutrality of money holds. Relying on these strong assumptions, an efficient market hypothesis asserts that asset prices always reflect all relevant information; thus it is impossible to cheat the financial market and obtain excessive profits by purchasing undervalued assets or selling overvalued assets ${ }^{23}$. In

19 Tuomas. Malinen, Income inequality in the process of economic development: an empirical approach. Research Reports Kansantaloustieteen tutkimuksia, 2012. No. 125:2011

20 Myriam J. Maier-Dimitrios N. Koumparoulis. Austrian Economics and the Financial Crisis of 2008. 2012. EuroEconomica. 31.3.

21 Claudiu-Gabriel Tiganas and Claudiu Peptine. The Austrian School Of Economics And Market Instability. CES Working Papers 5: 129-137. 2013.

22 Michael Roberts. The causes of the Great Recession: mainstream and heterodox interpretations and the cherry pickers. paper at the 10th conference of the Association of Heterodox Economist.2010.

23 See Eugene F. Fama. Efficient Capital Markets: a review and empirical work. Journal of Finance. 1970. Vol. 25(2): 383-417 and Anastasia Nesvetailova. Fragile Finance: Debt, Speculation and Crisis in the Age of Global Credit. Basingstoke: Palgrave Macmillan. 2007. 
neoclassical theory, supply and demand mechanisms always make certain of a tendency toward an equilibrium state by accommodating the most efficient economic outcome possible. Thus, crises can only outbreak as a consequence of external shocks that disturb the equilibrium impermanently ${ }^{24}$. In other words, crises are considered a self-adjustment mechanism of the economy to overcome the disturbance resulting from external shocks.

On the other hand, studies conducted by mainstream economists on financial crises in developing countries have revealed that this orthodox explanation of crises does not offer a plausible ground for economic downturns. As a new-Keynesian economist, Krugman (1979) offered a model on financial crises known as the "first-generation model." This model is one of the first mainstream explanations of crises that sees the weakness of economic fundamentals to the balance of payment imbalances as the main source of financial crises ${ }^{25}$. Following the increasing frequency of financial crises in emerging countries in the 90s, the first-generation model pioneered its successor models, which are the second-, third-, and fourth-generation models of financial crises ${ }^{26}$. After the collapse of the European Exchange Rate Mechanism (ERM) in 1992-1993, Obstfeld (1994) proposed the second-generation model to explain this incident, which the first-generation model was unable to explain given the absence of the weakness of economic fundamentals. This type of model explains the crises as a result of the exchange rate regime's changing expectations on the government's policy choice by making a trade-off between credibility in the long-run and flexibility in macroeconomic activities in the short-run ${ }^{27}$.

Following the eruption of the Asian crises of the late 1990s, the third-generation crisis model emerged that investigates how quickly worsening in balance sheets can lead to a crisis by inducing fluctuating asset prices and exchange rates. This generation of models focuses on the self-fulfilling structure of crises and vulnerabilities in corporate and financial sectors arising from the balance sheet deterioration that can cause financial crises. In particular, the banking sector with large debts and over-borrowing is likely to trigger a crisis if a sudden change in expectations causes a run on the bank $k^{28}$.

The fourth-generation crises model differs from the previous ones that can be identified as a currency crisis model. It is mainly a general financial crisis model that examines the other asset prices as the major sources of financial crises $^{29}$. Extending the earlier literature by introducing

24 Clarke, Ibid.

25 Gurudeo Anand Tularam and Bhuvaneswari Subramanian. Modeling of financial crises: a critical analysis of models leading to the global financial crisis. Global Journal of Business Research. 2013. 7(3):101-124.

26 Jesús Munoz. Orthodox versus Heterodox (Minskyan) Perspectives of Financial Crises: Explosion in the 1990s versus Implosion in the 2000s. Levy Economics Institute of Bard College Working Papers, (695). 2011.

27 Alves Jr Antônio et al. Currency crises, speculative attacks and financial instability in a global world: a Post Keynesian approach with reference to Brazilian currency crisis (No. 2001-2007). Universidade Federal do Rio Grande do Sul, Curso de Pós-Graduação em Economia. 2001.

29 Paul Krugman. Crises: The Next Generation?. Paper Presented at Conference Honoring Assaf Razin, Tel Aviv. 2001. 
the institutional issues associated with macroeconomic vulnerabilities, which cause problems in the banking sector, fourth-generation models also focus on the political instability in anticipating financial crises ${ }^{30}$. When the banks and macroeconomic indicators are fragile enough, a sudden change in expectations can trigger a financial crisis.

A more effective new-Keynesian opposition to the orthodox explanation of crises assuming that there is no asymmetric information in efficient and endogenously stable markets is the asymmetric and imperfect information theory proposed by Akerlof (1970) and Stiglitz and Rothschild (1976). This theory implies that economic transactions include participants with different degrees to access to information and a market participant with a better degree to access information to take advantage of it for gaining more profit. Despite the existence of financial intermediaries for minimizing the information and transaction costs, the resulting inefficiency can create market disequilibrium endogenously. Therefore, a serious crisis may outbreak due to the internal factors and external shocks as well as a sudden change in expectations ${ }^{31}$.

The asymmetric information theory gave rise to another opposition to the inherent stability notion of market, which is known as the behavioral finance theor $\mathrm{y}^{32}$. Being introduced by Kahneman and Tversky (1979) and developed by Shefrin and Statman (1994), Shiller (1995, 2000), Shleifer (2000), and Akerlof and Shiller (2009), the field of behavioral finance sees financial crises and bubbles as the result of the emotional and cognitive biases of the market participants.

However, stochastic general equilibrium (DSGE) modeling, which is the most widespread mainstream method of recent times used by both policymakers and academics, asserts that the economy will always tend to achieve equilibrium. Essentially a short-run model, this approach establishes fully structural models and facilitates the analysis of policies by setting strong assumptions about the markets, variables, and functional forms. Under the assumptions of utility maximizing and rational consumers' expectations, profit maximizing producers, and the existence of representative agents with rational expectations, the market structure may be disrupted, but market clearance will occur by a dynamic adjustment process in a few quarters ${ }^{33}$. On the other hand, because of their disadvantages and failure in predicting the 2008 global financial crisis, the practicability and extensive usage of DSGE models have been criticized by mainstream economists such as Buiter (2009), Spaventa (2009) Stiglitz (2011), and Krugman (2011).

As it can be understood from the previous discussion, changes in income distribution do not have a significant role in the mainstream explanation of crises. From the orthodox economics

30 Tularam and Subramanian, Ibid.

31 Santonu Basu. Incomplete information and asymmetric information. Zagreb International Review of Economics and Business. 2001. 4(2):23-48.

32 George Akerlof. Behavioral macroeconomics and macroeconomic behaviour. American Economic Review. 2002. 92(3). 411-433.

33 See Norberto Garcia. DSGE macroeconomic models: A critique. Economie Appliquee. 2011. 64(1): 149 and Giorgio Fagiolo and Andrea Roventini.. Macroeconomic policy in dsge and agent-based models. Revue de l'OFCE. 2012 (5): 67-116. 
point of view, crises are not inherent to the economy, and an instability that can only arise from exogenous shocks will be cleared by the forces of supply and demand. However, the first-, second-, third-, and fourth-generation mainstream models see crises as inherent to the economy due to the weaknesses of economic fundamentals. This weaknesses are derived from the sudden changes in expectations and the income redistribution, which may occur through several channels, such as the slowdown in economic activities, changes in relative prices, and fiscal contraction, is just one of the outcomes of crises.

Furthermore, behavioral theories of finance do not discuss the changes in individuals' inequality levels as the source of the changes in their behaviors ${ }^{34}$. Likewise, As Stiglitz (2011) stated, DGSE models that mainly rely on the representative agent with rational expectations have no room for distributive issues. For instance, changes in interest rates and wages may have serious distributive effects in general, but the structure of DGSE models lets the workers compensate for their loss in wage with their profit income gained as "owners."

However, the inability of these mainstream models and approaches to predict and explain the 2008 global financial crisis has motivated mainstream economists to re-assess their basic assumptions and re-evaluate the role of income distribution and inequality in their explanation of crises. These discussions will be examined in detail further.

\section{The Role of Income Distribution in The Heterodox Explanations of The Global Financial Crisis}

The orthodox explanations of crises' failure to anticipate and estimate the eruption of the U.S. economy's subprime crisis in 2008 and its transformation to a global financial crisis that rapidly spread to other economies gave a rise to interest in Heterodox tradition in economics.

Within this context, Marxian explanations of crises have been revisited and reinterpreted by heterodox political economists, particularly from the Post-Keynesian strand. These interpretations of recent crisis can be roughly grouped in two classes: explanations that see the decreasing profit rates in the real sector as the main cause of the subprime crisis $^{35}$ and explanations that see the increasing inequality and overcoming the under-consumption through increasing debt of households as the cause of subprime crisis ${ }^{36}$. However, particularly with the effect of PostKeynesians' contributions to the reinterpretation of both theories to explain the subprime crisis,

34 Goda, Ibid.

35 Robert Brenner and Jeong Seong-jin. Overproduction not Financial Collapse is the Heart of the Crisis: The US, East Asia, and the World. 2009. The Asia- Pacific Journal (February 7).

36 See William K. Tabb. Marxism, crisis theory and the crisis of the early 21st century. Science and Society. 2010. 74(3): 305-323; Özlem Onaran. Global crisis and the policy reaction in Western and Eastern European Union: can policy save capitalism from itself? 2010a. Retrieved at 26.02.2012 fromhttp://internationalviewpoint.org/spip. php?article1797 and Özlem Onaran. The Crisis of Capitalism in Europe, West and East. Monthly Review. 2010b. 62(5): 18-33. 
the effect of financialization on the emergence of the crisis is not just embedded in both groups' explanations, but it is also examined as an independent factor within the context of the Marxian tradition.

Heterodox economists who explain the subprime crisis on the basis of the Marxian falling rate of profit theory define financialization as a result of the falling rate of profits in the real sector. With the increase in the ratio of constant capital to variable capital in the post-1970 era, the surplus value obtained from capital investment decreased, which led to fewer investment activities in the real sector. As a consequence of the investors' searches for new and more profitable investment opportunities, the importance and variety of the financial investment instruments and financial markets significantly increased. The contribution of the financial sector to the overall profit in the economy increased from $10 \%$ to $40 \%$ from the early 1980 s to 2007 . While the ratio of financial assets to aggregate output was about 4 to 1 in the 1970s, it was approximately 10 to 1 in 2007 . In the global economy, the ratio of the global financial assets to global production increased to $356 \%$ from $119 \%$ between 1980 and $2007^{37}$. Consequently, this financialization phenomenon gave rise to more speculative assets and led to the subprime crisis. According to this line of thought, income inequality stemming from diminishing real wages and limited social benefits accelerated the subprime crisis by increasing the demand for speculative assets. On the other hand, it is just another result of the falling rate of profits along with the dominance of financial markets i.e. financialization, speculation, and securitization ${ }^{38}$.

The explanation of the subprime crisis regarding the low rate of profit as the main trigger has been challenged by some heterodox economists whose arguments rely on the recovery of the profit rates beginning in the 1980s, thanks to the stagnant real wages and increasing exploitation of labor ${ }^{39}$. Further, decreasing debt-to-profit ratios of non-financial corporate businesses protected most of these corporations from bankruptcy. On the other hand, this recovery of the profit rates did not stimulate investment due to capitalists' choice to increase their own dividends ${ }^{40}$.

On the other hand, the main argument of the heterodox economists who interpret the U.S. subprime crisis on the basis of the "under-consumption/over-production theory" is that, along with the other structural complications such as low interest rates, financial deregulation, speculative investment, and financial innovation, one of the fundamental causes of the crisis was the increasing indebtedness of the lower-income group who suffered from under-consumption due to the declining real wages in the U.S. economy ${ }^{41}$. After the post-1970 era, a significant increase in the corporate profits and top management salaries resulted in a growing money capital, which

\footnotetext{
37 Smith, Ibid.

38 Goda, Ibid.

39 Fred Moseley. Some Notes on the crunch and the crisis. International Socialism, issue 119. 2008. Retrieved at 10.02.2016 from http://www.isj.org.uk/?id=463

40 Photis Lysandrou. Global inequality, wealth concentration and the subprime crisis: a Marxian commodity theory analysis. Development and Change. 2011. 42.1:183-208.

41 Smith, Ibid; Tabb, Ibid; Onaran, 2010a, Ibid; Onaran, 2010b, Ibid.
} 
needed to be absorbed by the aggregate demand. On the other hand, the purchasing power of average households was not sufficient to provide the required aggregate demand level due to their decreasing real wages. Accordingly, the spending capacity of these households was increased with indebtedness, which was an outcome of the financialization process. While the workers with declining or stagnating real wages were encouraged to create effective demand by getting into more debt, financialization in the economy maintained even more debt instruments to them. After the point when the debt accumulation of the household sector became unsustainable, the financial sector collapsed, having a domino effect on the rest of the U.S. economy and the global financial markets.

As it indicated before, Post-Keynesian interpretations regarding the source of the subprime crisis are predominantly grouped into three categories: Minskian instability, financialization and stockflow consistent models.

Being proposed in an era with a primitive financial sector and being limited to firms and their search for higher profit only, Minsky's original hypothesis of financial instability naturally does not consider the household sector and their risky debt structure. However, the applicability of its main framework to current problems made it very predominant in heterodox literature on the subprime crisis. Specifically, some economists from heterodox traditions, such as Moseley, $\mathrm{O}^{\prime} \mathrm{Hara}^{42}$, have argued that the subprime crisis had predominantly Minskian characteristics instead of having traditional Marxian features. Even the leading mainstream economists, such as Stiglitz (2009a), Yellen (2009), and Krugman (2012), admitted that, after the global financial crisis, a shift in interest toward Minsky's financial instability occurred and it is well worth attention ${ }^{43}$. The emphasis of Minsky's hypothesis on the institutions, deregulation, securitization, and financial innovation in financial markets makes it very convenient to explain the subprime crisis since the unsustainable bubble in housing prices and the emergence of toxic mortgage products in the subprime market were derived from the deregulation and innovation in financial markets that created speculative and Ponzi financing options for households ${ }^{44}$. As such in the original version of Minsky's financial instability hypothesis, income distribution and inequality do not play an important role in the emergence of the crisis in most of the contemporary versions of this hypothesis. Although there have been a few efforts ${ }^{45}$ to embed the inequality in the analysis, Minsky's financial instability has been criticized by the proponents of the financialization theory because of its lack of aggregate demand and income distribution ${ }^{46}$.

42 Moseley, Ibid;; and Phillip A. O’Hara, The global securitized subprime market crisis. Review of Political Economics. 2009.

43 Lawrence W. Nowicki, New-Keynesians, Post-Keynesians and the Financial Crisis. Proceedings of the Northeast Business \& Economics Association. 2013.

44 Alessandro Vercelli. "Minsky Moments, Russell Chickens and Grey Swans: The Methodological Puzzles of Financial Instability Analysis." Minsky, Crisis and Development. Palgrave Macmillan UK.15-31. 2010.

45 Trygve Larsen Morset. Inequality as a Cause of Systemic Banking Crises $₫$ Some New Theory and Evidence. Master Thesis. Lund University. 2013. 
As it discussed in Section 2, the financialization theory placed inequality, income distribution, and aggregate demand in the center of the analysis regarding the crises. Financialization has been effecting households and functional income distribution adversely through the rising income in financial rentiers and top management salaries at the expense of regular workers' wages and the weakening bargaining power of labor and labor unions. Weakening aggregate demand, which was the natural consequence of increasing income inequality, was overcome with debt-financed consumption accompanied by a reduction in household savings and private housing investment in the U.S. While the top $1 \%$ of households rapidly increased their share in the national income, poor and middle income households tried to sustain their livelihood while increasing their debt level. In addition, the deregulation in the finance sector made borrowing easier for individuals who tried to sustain a lifestyle and a consumption level they could not afford with their actual earnings. With the innovation in the finance sector that created more speculative and Ponzi scheme debt instruments, these households became over-indebted, and when their debt accumulation could no longer be sustained, the subprime crisis erupted ${ }^{47}$. The opponents of the financialization theory explain the subprime crisis using Minskian instability and a strong emphasis on inequality.

Another approach that post-Keynesians have employed to explain the causes of the subprime crisis are the stock-flow consistent models, which are basically accounting models based on the balance sheets of the sectors of an economy and the money flows among them. The inability of the mainstream general equilibrium models to anticipate the subprime crisis increased the interest of heterodox economists in stock-flow consistent models established to estimate financial crises and recessions. In particular, adding households as a sector along with firms and government sectors made it possible to observe the wealth and debt levels of society and imbalances in crosssectoral flows ${ }^{48}$. On the other hand, this approach cannot fully capture the income redistribution between individuals in a sector or divide households into rentiers bnatural level and prices in the housing sector started to decrease. The resulting housing bubble caused the subprime crisis, which transformed into a global financial crisis later. Therefore, the Federal Reserve's optimistic assumption regarding their power of intervening in the economy at any time was not proven to be right ${ }^{49}$. On the other hand, due to Austrian School's rejection of the econometric and statistical

47 See Thomas I. Palley. Financialization: What it is and Why it Matters. PERI Working Paper No. 153. 2007; Engelbert Stockhammer. Rising inequality as a cause of the present crisis. Cambridge Journal of Economics. 2015.39.3:935958; Özlem Onaran. From wage suppression to sovereign debt crisis in Western Europe: who pays for the costs of the crisis? International Journal of Public Policy. 2011. 7(1/2/3): 51 - 69; Till Van Treeck and Simon Sturn. Income inequality as a cause of the Great Recession? : A survey of current debates. ILO Working Papers 470934, International Labour Organization. 2012 and Jo. Michell, Working paper no. 41: Factors generating and transmitting the crisis: Functional distribution of income. Working Paper. FESSUD, Leeds. Available from: http://eprints.uwe.ac.uk/23428 2014a.

48 See Dirk Bezemer. Causes of Financial Instability: Don't Forget Finance. Levy Economics Institute of Bard College Working Paper No. 665. 2011. Available at SSRN: http://ssrn.com/abstract=1808020 or http://dx.doi.org/10.2139/ ssrn.1808020 and Eugenio, Caverzasi and Antoine Godin. Stock-flow consistent modeling through the ages. Levy Economics Institute of Bard College Working Paper, (745). 2013. 
analyses, their literature on the global financial crisis is purely theoretical and not supported by empirical findings that can prove the significance of their arguments ${ }^{50}$.

\section{The Role of Income Distribution in The Mainstream Explanations of The Global Financial Crisis}

The eruption of the subprime and the following global financial crisis put forward several possible factors that might have caused the crisis among mainstream economists. Within this framework, some of the most discussed main causes of the crisis are the lack of regulation ${ }^{51}$, innovation in financial markets ${ }^{52}$ and global imbalances accompanied by misguided monetary policy on the basis of setting very low interest rates $^{53}$. On the other hand, apart from its possible facilitating role, increasing income inequality is considered a root cause of the crisis in the mainstream economists' discussions of the subprime crisis $^{54}$.

Nonetheless, the idea of the absence of the link between rising inequality and the subprime crisis has been challenged by increasing numbers of mainstream economists. One of the first and most influential arguments suggesting a relationship between increasing income inequality and the subprime crisis was put forward by Rajan ${ }^{55}$. According to Rajan, the main reason for the subprime crisis was the government's failure to deal with the increasing income inequality beginning in the late 1970s, which was mainly derived from the poor education system that could not provide the high-skilled workers required to perpetuate the skill-biased technological changes in the U.S. economy. Instead of developing policies that provide permanent solutions for educational and distributive problems, the government chose to promote de-regulation in the finance sector, which provided mortgage loans and other debt instruments for the low-income segment, to expand consumption levels. The resulting credit expansion in the U.S. economy caused a boom in consumption levels and the unsustainable debt accumulation of households. When housing prices started to decrease in 2007, the fragile financial and banking system collapsed. Accordingly, Kumhof and Ranciere ${ }^{56}$ tested Rajan's arguments by employing a DSGE model and presented that

50 Nicholas Fett. The Effect of Monetary Policy on Real growth Cycles. Issues in Political Economy. 27-20:7 .2011.

51 See Alex Brummer, The crunch: How greed and incompetence sparked the credit crisis. 2009. Random House and Karl Whelan. Global imbalances and the financial crisis. University College Dublin. School of Economics, 201004. 2010.

52 See Robert W Kolb. Lessons from the financial crisis: Causes, consequences, and our economic future. Vol. 12. John Wiley \& Sons. 2010 and Carmen M. Reinhart-Kenneth S. Rogoff. Is the 2007 US sub-prime financial crisis so different? An international historical comparison. No. w13761. National Bureau of Economic Research, 2008. Obstfeld, Maurice, and Kenneth Rogoff. Global imbalances and the financial crisis: products of common causes. paper prepared for the Federal Reserve Bank of San Francisco's conference on Asia and the Global Financial Crisis. 2009.

Goda, Ibid.

55 Raghuram G. Rajan, Fault Lines. How Hidden Fractures Still Threaten the World Economy. Princeton: Princeton University Press. 2010.

56 Michael Kumhof and Romain Ranciere. Inequality, leverage and crises. IMF Working Paper No. 268. 2010. 
increasing inequality and stagnant wages at the bottom of the income distribution led workers to become over-indebted to maintain their standard of living and living conditions. When an external shock hit the economy, the financial crisis erupted due to the fragility of these people and the financial system.

However, a number of opposing studies to Rajan's framework emerged. In contrast to Rajan, Bordo and Meissner ${ }^{57}$ found little evidence linking the global financial crisis to rising inequality and referred to economic expansion and low interest rates as the two main causes of the crisis. Then, Atkinson and Morelli ${ }^{58}$ stated that the causality of the rising inequality is not easy to establish and evidence on the increasing inequality following the financial crisis is stronger. Rohá c $^{59}$ also expressed that there is no convincing link between high levels of inequality and the global financial crisis.

On the other hand, a number of mainstream economists, such as Reich ${ }^{60}$, Milanovic ${ }^{61}$, Piketty ${ }^{62}$, Acemoglu $^{63}$, Atkinson and Morelli ${ }^{64}$, Krugman ${ }^{65}$, and Stiglitz ${ }^{66}$ also opposed the orthodox explanation of crises that assumes there is no link between increasing economic inequality and economic downturns. Supporting Rajan's ${ }^{67}$ argument, Milanovic ${ }^{68}$ asserted that the underlying cause of the crisis was the a credit-fueled system created by the compatible interests of the financial sector, which was searching for further lending opportunities, and the politicians who were eager to find a quick solution for the stagnant income of the middle class. Therefore, middle- and lower-class people used all the borrowing opportunities offered by this credit-fueled system that were bending their budget constraints to sustain a lifestyle that they otherwise would not have been able to afford. Similar to Milanovic, Stiglitz also emphasized the ambition of the middle and

57 Michael Bordo and Christopher M. Meissner Does inequality lead to a financial crisis?. Journal of International Money and Finance. 2012. 31(8): 2147-2161.

58 Anthony Atkinson and Salvatore Morelli. Economic crises and Inequality. UNDP-HDRO Occasional Papers, (2011/6). 2011.

59 Dalibor Roháč, Does inequality matter?. Adam Smith Institute Briefing Paper, 17. 2011.

60 Robert B. Reich, Aftershock: The next economy and America's future. Vintage. 2010.

61 Branko Milanovic The Haves and the Have-Nots: A Brief and Idiosyncratic History of Global Inequality. Basic Books. 2010.

62 Thomas Piketty. On the long-run evolution of inheritance: France 1820-2050. The Quarterly Journal of Economics. 2011. 126 (3): 1071-1131.

63 Daron Acemoglu Thoughts on inequality and the financial crisis. In AEA meeting, Denver (Vol. 7). 2011

64 Atkinson and Morelli. Ibid.

65 Paul Krugman. Inequality and crises: coincidence or causation?V ad \$ dress at the Alphonse Weicker Foundation. 2010.

66 Joseph Stiglitz, The Current Economic Crisis and Lessons for Economic Theory. Presidential Address to the Eastern Economic Association. The Eastern Economic Journal. 2009a. 35 (3): 281-296; Joseph Stiglitz, The global crisis, social protection and jobs. International Labour Review. 2009b. 148(1-2): 1-13; Joseph Stiglitz, Freefall: America, free markets, and the sinking of the world economy. WW Norton \& Company. 2010; Joseph Stiglitz, Macroeconomic fluctuations, inequality, and human development. Journal of Human Development and Capabilities. 2012a 13(1):31-58; and Joseph Stiglitz, The price of inequality. Penguin Books: London. $2012 \mathrm{~b}$.

67 Rajan, Ibid.

68 Milanovic, Ibid. 
lower classes to live beyond their means as the fueling force of the consumption boom created by the housing and stock market bubbles. These bubbles were the results of the easy monetary policy that was used to overcome the insufficient aggregate demand in the U.S. and in the global economy after 2001. According to Stiglitz, the root cause of all these macroeconomic failures is the imperfect and asymmetric information phenomenon, which was theorized by himself and Rothschilds in $1976^{69}$. The political power of the top income earners increased at the expense of the power of the working class due to the weakening labor unions, deregulations, and globalization. In addition, the financialization and skill-biased technological change increased the degree of income polarization. In line with Stiglitz, Krugman ${ }^{70}$ emphasized the role of the increasing top income share in the global financial crisis and stated that the increasing inequality before the two big crises in American history was not a coincidence and extreme inequality prompted the overconsumption of the lower- and middle- income classes, which led to the subprime crisis. Acemoglu ${ }^{71}$ stated the increasing top income share and lack of regulation of the financial sector was the possible driving force behind the global financial crisis. Likewise, Piketty ${ }^{72}$ claimed that the increasing top income was an important cause of the global financial crisis. Atkinson and Morelli ${ }^{73}$ also showed that the rising inequality due to the share of the top income class is driven by high salaries much more than high returns to capital.

The significant role of the top income share within the context of the global financial crisis gave rise to another question regarding whether an income redistribution at the expense of the top income earners occurred or not. Since the income structure of the top income share is more fragile in financial crises, one can assume that a reduction in income inequality might have occurred following the global financial crisis. However, the facts do not support this hypothesis. De Beer ${ }^{74}$ showed that in a small majority of the European Union countries, inequality dropped following the global financial crisis; therefore, no uniform pattern has been found. Furthermore, as a recent $\mathrm{OECD}^{75}$ report presented, the global financial crisis distorted the top income share only temporarily. Although the share of the top income group could not recover its records over the past three decades, the real income of the lower $90 \%$ of the population was stagnating, while that of the top $1 \%$ rose by $4 \%$ as of 2010 .

69 Joseph Stiglitz and Rothschild, Michael. Equilibrium in competitive insurance markets. Quarterly Journal of Economics. 1976. 90:629-649.

70 Krugman, Inequality and crises...

71 Acemoglu, Ibid.

72 Piketty, Ibid.

73 Atkinson and Morelli, Ibid.

74 Paul De Beer The Impact of the Crisis on Earnings and Income Distribution in the EU. Brussels: European Trade Union Institute. 2012.

75 OECD. Focus on Top Incomes and Taxation in OECD Countries: Was the crisis a game changer? 2015. OECD Report 


\section{Conclusion}

All Marxian crisis theories are based on the notion that class struggles over income distribution and crises are inherent to capitalist economies. While the Marxian under-consumption theory claims that increasing income inequality is the main cause of crises, Marxian profit squeeze theory sees the decreasing income inequality between workers and capitalists as the main root of the crises. On the other hand, according to the Marxian tendency for the profit rate to fall theory, income redistribution among classes is not a root of capitalist crises, but it is one of the consequences of capitalist accumulation. In line with the Marxian economists, most post-Keynesian economists claim that crises and class struggles over income distribution are endogenous in capitalist economies. Theories of economic instability that became prominent in post-Keynesian literature are the Minskian instability hypothesis, which does not see inequality as a cause of financial crises, and financialization, which put inequality in the center of the analysis. In contrast to most of the other heterodox traditions, the Austrian school of economics sees the income inequality as the natural cause of the economic mechanism and claims that following policies that force an income redistribution disrupts the economic system. Accordingly, Austrian economists' view that the misguided monetary policies based on low levels of interest rates as the main cause of the crisis does not consider inequality a facilitating factor. On the other hand, most mainstream economists accept the endogenous stability of the economy as the norm and see exogenous shocks as responsible for short-term economic instability. According to mainstream economists, the forces of supply and demand always clear the market, and income redistribution is not the root of the crises. However, after the global financial crisis, mainstream economics started to experience a paradigm shift by questioning the role of inequality in the occurrence of the crises. Following the study of Rajan ${ }^{76}$, a number of mainstream economists claimed that the increasing income inequality was a root cause of the subprime crisis, and rejected the orthodox explanation of the financial imbalances. Nevertheless, a considerable number of mainstream economists have focused on the role of the top income share and deregulations in financial sectors within the context of their discussion on the subprime crisis.

Although there are fundamental differences between heterodox and mainstream strands of economics, they have some common grounds in their explanations regarding the emergence of the subprime crisis. Deregulation in financial markets and increasing importance of financial motives are the predominantly discussed factors among both heterodox and mainstream economists. 


\section{References}

ACEMOGLU, Daron. Thoughts on inequality and the financial crisis. In AEA meeting, Denver (Vol. 7). 2011

AKERLOF, George. Behavioral macroeconomics and macroeconomic behaviour. American Economic Review. 2002. 92(3). 411-433.

AKERLOF, George. The market for lemons: quality uncertainty and the market mechanism. Quarterly Journal of Economics. 2011. 84: 488-500.

ANTONIO, Alves Jr., et al. Currency crises, speculative attacks and financial instability in a global world: a Post Keynesian approach with reference to Brazilian currency crisis (No. 2001-2007). Universidade Federal do Rio Grande do Sul, Curso de Pós-Graduação em Economia. 2001.

ARESTIS, Philip. Post-Keynesian economics: towards coherence. Cambridge Journal of Economics. 1996. 20(1): 111-135.

ATKINSON, Anthony. et al. Top Incomes in the Long Run of History. Journal of Economic Literature. 2011. 49 (1): 3-71.

ATKINSON, Anthony., Salvatore Morelli. Economic crises and Inequality. UNDP-HDRO Occasional Papers, (2011/6). 2011.

BARAN, Paul. et al. Monopoly capital: An essay on the American economic and social order. Vol. 73. NYU Press. 1966.

BARRON, Patrick. Why Monetary Expansion must stop. Mises Daily. 2011. available at https://mises.org/ library/why-monetary-expansion-must-stop

BARONIAN, Laurent, Marx and Living Labour. Routledge. 2013.

BASU, Santonu. Incomplete information and asymmetric information. Zagreb International Review of Economics and Business. 2001. 4(2):23-48.

BELL, Peter and Cleaver, Harry. Marx's theory of crisis as a theory of class struggle. The Commoner. 2002. 5:1-61.

BELLOFIORE, Riccardo. From Marx to Minsky: The Universal Equivalent, Finance to Production and the Deepening of the Real Subsumption of Labour under Capital in Money Manager Capitalism. In Ganssmann, H. eds. "New approaches to monetary theory. Interdisciplinary perspectives". Routledge: Abingdon \& New York, 2011. pp. 191-211.

BEZEMER, Dirk. Causes of Financial Instability: Don't Forget Finance. Levy Economics Institute of Bard College Working Paper No. 665. 2011. Available at SSRN: http://ssrn.com/abstract $=1808020$ or http://dx.doi.org/10.2139/ssrn.1808020

BOETTKE, Peter J and Coyne, Christopher J. The debt-inflation cycle and the global financial crisis. Global Policy. 2011. 2.2: 184-189.

BORDO, Michael and Meissner, Christopher M. Does inequality lead to a financial crisis?. Journal of International Money and Finance. 2012. 31(8): 2147-2161.

BRENNER, Robert and SEONG-JIN Jeong. Overproduction not Financial Collapse is the Heart of the Crisis: The US, East Asia, and the World. 2009. The Asia- Pacific Journal (February 7).

BRUMMER, Alex. The crunch: How greed and incompetence sparked the credit crisis. 2009. Random House.

BUITER, Willem. The unfortunate uselessness of most'state of the art'academic monetary economics. VoxEU, Research-based policy analysis and commentary from leading economists. 2009.

CAIANI, Alessandro. et al. Agent Based-Stock Flow Consistent Macroeconomics: Towards a Benchmark Model. Columbia Business School Research Paper No. 15-87. 2015. Available at SSRN: http:// ssrn.com/abstract=2664125 or http://dx.doi.org/10.2139/ssrn.2664125

CAVERZASI, Eugenio and GODIN, Antoine. Stock-flow consistent modeling through the ages. Levy Economics Institute of Bard College Working Paper, (745). 2013. 
CLAESSENS, Stijn and KOSE, Ayhan. Financial Crises Explanations, Types, and Implications (No. 13-28). International Monetary Fund. 2013.

CLARKE, Simon. Marx's Theory of Crisis. Macmillan Press: Basingstoke. 1994

DE BEER, Paul. The Impact of the Crisis on Earnings and Income Distribution in the EU. Brussels: European Trade Union Institute. 2012.

EVANS, Trevor. Marxian and post-Keynesian theories of finance and the business cycle. Capital \& Class. 2004. 28(2): 47-100.

EVANS, Trevor. Five explanations for the international financial crisis. IPE Working Paper No. 08/2010. 2010.

EZUHO, Elom. Income Inequality, Over-indebtedness and Financial Instability: Essay on a KeynesGoodwin-Minsky Macrodynamic Model. In 15th Conference of the Research Network Macroeconomics and Macroeconomic Policies (FMM), Berlin 2011. pp. 28-29.

FAGIOLO, Giorgio and Roventini, Andrea. Macroeconomic policy in dsge and agent-based models. Revue de l'OFCE. 2012 (5): 67-116.

FAMA, Eugene F. Efficient Capital Markets: a review and empirical work. Journal of Finance. 1970. Vol. 25(2): 383-417.

FETT, Nicholas. The Effect of Monetary Policy on Real growth Cycles. Issues in Political Economy. .2011 27-20:7.

GARCIA, Norberto. DSGE macroeconomic models: A critique. Economie Appliquee. 2011. 64(1): 149.

GATTI, Domenico Delli and GALLEGATI, Mauro. Financial instability, income distribution, and the stock market. Journal of Post Keynesian Economics. 1990. 12(3): 356-374.

GODA, Thomas. 2013. The role of income inequality in crisis theories and in the subprime crisis. Post Keynesian Economics Study Group Working Paper, 1305.

GODLEY, Wynne and MCCARTHY, George. Fiscal policy will matter. Challenge. 1998. 41(1): 38-54.

GODLEY, Wynne. Seven Unsustainable Processes: Medium-Term Prospects and Policies for the United States and the World. Strategic Analysis, The Levy Economics Institute of Bard College. 1999.

GODLEY, Wynne and Lavoie, Marc. Fiscal policy in a stock-flow consistent (SFC) model. Journal of Post Keynesian Economics. 2007a. 30(1): 79-100.

GODLEY, Wynne and Lavoie, Marc. Monetary Economics - An Integrated Approach to Credit, Money, Income, Production and Wealth, 2007b, Palgrave Macmillan, Basingstoke, UK

GOLDSTEIN, Jonathan. The cyclical profit squeeze: a Marxian microfoundation. Review of Radical Political Economics. 1985. 17(1-2): 103-128.

HEIN, Eckhard. A (Post-) Keynesian perspective on" financialisation” (No. 1/2009). IMK Study. 2009.

HEIN, Eckhard. Financialization, distribution, capital accumulation, and productivity growth in a postKaleckian model. Journal of Post Keynesian Economics. 2012. 34(3): 475-496.

JARSULIC, Marc. Financial instability and income distribution. Journal of Economic Issues. 198822(2), 545-553.

KAHNEMAN, Daniel and Tversky, Amos. Prospect Theory: An Analysis of Decision Under Risk, Econometrica. 1979. 47: 263-291.

KEEN, Steve. Post Keynesian theories of crisis. American Journal of Economics and Sociology. 2015. 74(2): 298-324.

KOLB, Robert W. Lessons from the financial crisis: Causes, consequences, and our economic future. Vol. 12. John Wiley \& Sons. 2010.

KOTZ, David M. Social structures of accumulation, the rate of profit, and economic crises, paper written for a Festschrift in honor of Thomas E. Weisskopf, University of Massachusetts. 2011.

KINSELLA, Stephen. et al. Income Distribution in a Stock-Flow Consistent Model with Education and Technological Change. Eastern Economic Journal. 2011. 37(1): 134-149. 
KRUGMAN, Paul. A model of balance-of-payments crises. Journal of money, credit and banking. 1979. 11(3): 311-325.

KRUGMAN, Paul. Crises: The Next Generation?. Paper Presented at Conference Honoring Assaf Razin, Tel Aviv. 2001.

KRUGMAN, Paul. Inequality and crises: coincidence or causation?V ad \$ dress at the Alphonse Weicker Foundation. 2010.

KRUGMAN, Paul. The Profession and the Crisis. Eastern Economic Journal. 2011. (37): 307-312.

KRUGMAN, Paul. End This Depression Now!. New York: Norton. 2012.

KUMHOF, Michael and Ranciere, Romain. Inequality, leverage and crises. IMF Working Paper No. 268. 2010.

KUMHOF, Michael., et al. Inequality, Leverage and Crises: The Case of Endogenous Default. IMF Working Papers, forthcoming, International Monetary Fund.Guilford Press. 2013.

LAIBMAN, David. Value, technical change, and crisis: Explorations in Marxist economic theory. ME Sharpe. 1992.

LAVOIE, Marc. Introduction to Post-Keynesian Economics. Houndmills: Palgrave Macmillan. 2006.

LAVOIE, Marc. Financialisation issues in a Post-Keynesian stock-flow consistent model. Intervention. European Journal of Economics and Economic Policies. 2008. 5(2):335-361.

LAVOIE, Marc and Godley, Wynne. Kaleckian models of growth in a coherent stock flow monetary framework: a Kaldorian view. Journal of Post Keynesian Economics. 311-277 :24.2 .2001.

LAWSON, Tony. Essays on: The Nature and State of Modern Economics. Routledge. 2015.

LYSANDROU, Photis. Global inequality, wealth concentration and the subprime crisis: a Marxian commodity theory analysis. Development and Change. 2011. 42.1:183-208.

MAIER, Myriam J. and Koumparoulis, Dimitrios N. Austrian Economics and the Financial Crisis of 2008. 2012. EuroEconomica. 31.3.

MAGDOFF, Foster., et al. The New Face of Capitalism: Slow Growth, Excess Capital, and a Mountain of Debt. Monthly Review. 2002. 53(11): 1-14.

MALINEN, Tuomas. Income inequality in the process of economic development: an empirical approach. Research Reports Kansantaloustieteen tutkimuksia, 2012. No. 125:2011

MICHELL, Jo. Working paper no. 41: Factors generating and transmitting the crisis: Functional distribution of income. Working Paper. FESSUD, Leeds. Available from: http://eprints.uwe.ac.uk/23428 2014a.

MICHELL, Jo. A Steindlian account of the distribution of corporate profits and leverage: A stock-flow consistent macroeconomic model with agent-based microfoundations. Post-Keynesian Study Group. Working Paper:14.12. 2014b.

MILANOVIC, Branko. The Haves and the Have-Nots: A Brief and Idiosyncratic History of Global Inequality. Basic Books. 2010.

MINSKY, Hyman P. Can 'It' Happen Again? Essays on Instability and Finance. Armonk, New York, M. E. Sharpe. 1982.

MINSKY, Hyman P. Stabilizing an Unstable Economy. New Haven and London, Yale University Press. 1986.

MORGAN, Jamie and Negru, Ioana. The Austrian perspective on the global financial crisis: A critique. Economic Issues. 2012. 17.2:27.

MORSET, Trygve Larsen. Inequality as a Cause of Systemic Banking Crises $\nabla$ Some New Theory and Evidence. Master Thesis. Lund University. 2013.

MOSELEY, Fred. The rate of profit and the future of capitalism. Review of Radical Political Economics. 1997. 29(4): 23-41.

MOSELEY, Fred. Some Notes on the crunch and the crisis. International Socialism, issue 119. 2008. Retrieved at 10.02.2016 from http://www.isj.org.uk/?id=463 
MUNOZ, Jesús. Orthodox versus Heterodox (Minskyan) Perspectives of Financial Crises: Explosion in the 1990s versus Implosion in the 2000s. Levy Economics Institute of Bard College Working Papers, (695). 2011.

MURPHY, Robert P . 'The Problems of Central Bank Planning. April 04, 2008a . https://mises.org/library/ problems-central-bank-planning

MURPHY, Robert P. An Open Letter to Gary Becker regarding Depressions. November 24, 2008b. https:// mises.org/library/open-letter-gary-becker-re-depressions.

NESVETAILOVA, Anastasia. Fragile Finance: Debt, Speculation and Crisis in the Age of Global Credit. Basingstoke: Palgrave Macmillan. 2007.

NOWICKI, Lawrence W. New-Keynesians, Post-Keynesians and the Financial Crisis. Proceedings of the Northeast Business \& Economics Association. 2013.

OBSTFELD, Maurice and ROGOFF, Kenneth. 2009. Global imbalances and the financial crisis: products of common causes. paper prepared for the Federal Reserve Bank of San Francisco's conference on Asia and the Global Financial Crisis.

OBSTFELD, Maurice. The Logic of Currency Crises. NBER Working Papers 4640, National Bureau of Economic Research, Inc. 1994.

O'DRISCOLL, Gerald P. Jr.. The FED can't solve our economic woes', The Wall Street Journal, 16August. 2010. http://www.wsj.com/articles/SB10001424052748704388504575418964014417740

OECD. Focus on Top Incomes and Taxation in OECD Countries: Was the crisis a game changer? 2015. OECD Report: available at http://www.oecd.org/els/soc/OECD2014-FocusOnTopIncomes.pdf

O’HARA, Phillip A.The global securitized subprime market crisis. Review of Political Economics. 2009. 41(3): 318-334.

ONARAN, Özlem. Global crisis and the policy reaction in Western and Eastern European Union: can policy save capitalism from itself? 2010a. Retrieved at 26.02.2012 fromhttp://internationalviewpoint.org/ spip.php?article1797

ONARAN, Özlem. The Crisis of Capitalism in Europe, West and East. Monthly Review. 2010b. 62(5): 18-33.

ONARAN, Özlem. From wage suppression to sovereign debt crisis in Western Europe: who pays for the costs of the crisis? International Journal of Public Policy. 2011. 7(1/2/3): 51 - 69.

ONARAN, Özlem - Galanis Giorgos. Is aggregate demand wage-led or proft-led? National and global effects. ILO Conditions of Work and Employment Series No. 31. 2012.

ORHANGAZI, Özgür. Financialisation and capital accumulation in the non-financial corporate sector: A theoretical and empirical investigation on the US economy: 1973-2003. Cambridge Journal of Economics. 2008. 32(6): 863-886.

PALLEY, Thomas I. Financialization: What it is and Why it Matters. PERI Working Paper No. 153. 2007.

PIKETTY, Thomas. On the long-run evolution of inheritance: France 1820-2050. The Quarterly Journal of Economics. 2011. 126 (3): 1071-1131.

RAJAN, Raghuram G. Fault Lines. How Hidden Fractures Still Threaten the World Economy. Princeton: Princeton University Press. 2010.

REICH, Robert B. Aftershock: The next economy and America's future. Vintage. 2010.

REINHART, Carmen M,. and Rogoff, Kenneth S. Is the 2007 US sub-prime financial crisis so different? An international historical comparison. No. w13761. National Bureau of Economic Research, 2008.

ROBERTS, Michael. The causes of the Great Recession: mainstream and heterodox interpretations and the cherry pickers. paper at the 10th conference of the Association of Heterodox Economist.2010.

ROHAC, Dalibor. Does inequality matter?. Adam Smith Institute Briefing Paper, 17. 2011.

SHAIKH, Anwar. An introduction to the history of crisis theories. In "US Capitalism in Crisis. Union for Radical Political Economics: New York. 1978. 
SHAIKH, Anwar. The first great depression of the 21st century. Socialist Register. 2011. 47: 44-63.

SHEFRIN Hersh and Statman, Meir. Behavioural Capital Asset Pricing Model. Journal of Financial and Quantitative Analysis. 1994. 29:323-349.

SHILLER, Robert J. Conversation, Information and Herd Behaviour, American Economic Review 1995. 85:181-185.

SHLEIFER, Andrei. Inefficient Markets: An Introduction to Behavioural Finance. Oxford, U: Press, Oxford. 2000.

STIGLITZ, Joseph and Rothschild, Michael. Equilibrium in competitive insurance markets. Quarterly Journal of Economics. 1976. 90:629-649.

STIGLITZ, Joseph. The Current Economic Crisis and Lessons for Economic Theory. Presidential Address to the Eastern Economic Association. The Eastern Economic Journal. 2009a. 35 (3): 281-296.

STIGLITZ, Joseph. The global crisis, social protection and jobs. International Labour Review. 2009b. 148(1-2): 1-13.

STIGLITZ, Joseph. Freefall: America, free markets, and the sinking of the world economy. WW Norton \& Company. 2010.

STIGLITZ, Joseph. Macroeconomic fluctuations, inequality, and human development. Journal of Human Development and Capabilities. 2012a 13(1):31-58.

STIGLITZ, Joseph. The price of inequality. Penguin Books: London. $2012 \mathrm{~b}$.

STOCKHAMMER, Engelbert. Financialisation and the slowdown of accumulation. Cambridge Journal of Economics. 2004. 28(5): 719-741.

STOCKHAMMER, Engelbert. Some stylized facts on the finance-dominated accumulation regime. Competition \& Change. 2008. 12(2): 184-202.

STOCKHAMMER, Engelbert. Rising inequality as a cause of the present crisis. Cambridge Journal of Economics. 2015.39.3:935-958.

TABB, William K.. Marxism, crisis theory and the crisis of the early 21st century. Science and Society. 2010. 74(3): 305-323.

TIGANAS, Claudiu-Gabriel and Peptine Claudiu. The Austrian School Of Economics And Market Instability. CES Working Papers 5: 129-137. 2013.

TULARAM, Gurudeo Anand and Subramanian, Bhuvaneswari. Modeling of financial crises: a critical analysis of models leading to the global financial crisis. Global Journal of Business Research. 2013. 7(3):101-124.

VAN TREECK, Till. The macroeconomics of 'financialisation' and the deeper origins of the crisis. IMK Working Paper No. 9. 2009.

VAN TREECK, Till and STUM, Simon. Income inequality as a cause of the Great Recession? : A survey of current debates. ILO Working Papers 470934, International Labour Organization. 2012.

VERCELLI, Alessandro. "Minsky Moments, Russell Chickens and Grey Swans: The Methodological Puzzles of Financial Instability Analysis.” Minsky, Crisis and Development. Palgrave Macmillan UK.15-31. 2010.

WHELAN, Karl. Global imbalances and the financial crisis. University College Dublin. School of Economics, 2010-04. 2010. 
